\title{
'Have you entered the storehouses of the snow?' China as a norm entrepreneur in the Arctic
}

\author{
Marc Lanteigne \\ Norwegian Institute of International Affairs, C. J. Hambros plass 2, 0164 Oslo, Norway \\ (marc.lanteigne@nupi.no)
}

Received May 2016; first published online 9 January 2017

\begin{abstract}
The admission of China as an observer in the Arctic Council in 2013 was a significant step in the ongoing evolution of the country's Arctic policy, but Beijing is still concerned about being accepted as a regional player given its geography and arguably lack of an Arctic history. As the Arctic becomes more open to scientific and economic engagement, China wishes to develop the idea of the Arctic as more of an international space as opposed to strictly a regional one, and to allow non-Arctic states, such as China itself, to become accepted as Arctic actors. However, in order to avoid a backlash from the Arctic states and potential exclusion from the region's development, Beijing cannot effectively be a unilateral 'norm-maker' in the Arctic. Instead, China has sought to develop the identity of a regional 'norm entrepreneur', engaging the Arctic on many levels to promote the norm of partnerships between Arctic and non-Arctic actors to promote positive sum outcomes. Through engagement via several areas and governmental levels, Beijing hopes to succeed in being widely viewed as a 'near-Arctic state' which can contribute to new norms, and possibly new regimes, in an Arctic which shows many signs of becoming further internationalised.
\end{abstract}

\section{Introduction}

During the past decade, the development of a stronger diplomatic and economic presence in the Arctic has assumed a higher priority for Beijing's expanded cross-regional diplomacy. The circumpolar north has been pushed into the global spotlight due to widespread environmental changes, especially ice erosion, raising questions concerning the region's economic and political future. Yet, what represents the best set of policies for Beijing to accomplish this goal, given a great number of political impediments? While the Arctic does not carry equal strategic weight in current Chinese foreign policy compared with other regions, such as Africa and the Middle East, Beijing is concerned with establishing an Arctic identity and being accepted as a regional stakeholder as areas of the far north open up to increased economic development. China is seeking to develop stronger partnerships with Arctic states, while gaining greater access to the region's resources, which include raw materials and fossil fuels, as well as sea lanes which have become more viable as the Arctic Ocean becomes ice-free for longer periods of time.

As a great power, Beijing has demonstrated scant evidence of highlighting the Arctic as a strategic priority, since this might risk provoking a backlash among Arctic states concerned about a Chinese challenge to the political and economic status quo in the region. However, Chinese anxieties about being excluded from the region due to its geographical isolation from the Arctic have prompted the country to develop policies, via governmental and sub-governmental initiatives, which have strengthened its position. Therefore, in this paper it is argued that Beijing has sought to engage the Arctic through policies consistent with the theories and practices of 'norm entrepreneurship' in international relations, in order to avoid being seen as either too assertive or too passive. The case of China in the Arctic stands as an example of how outside actors can engage Arctic governance and policy, and also contributes to the emerging studies of how states, even great powers, can be norm entrepreneurs when external and internal factors encourage such a stance.

\section{Thin ice: obstacles to China as an Arctic actor}

At first glance, despite the country's size and great power status, China would appear to face considerable obstructions in building an Arctic identity. First and most obvious, China lacks Arctic geography, as the shortest distance between the country's northernmost point (Mohe County, Heilongjiang province, situated at $\left.53^{\circ} 33^{\prime} \mathrm{N}\right)$ and the Arctic Circle is more than $1400 \mathrm{~km}$ (Tan 2011). Unlike other non-Arctic states active in the far north, such as France, Germany, Italy, the Netherlands, Poland and the UK, Beijing does not have a long history of Arctic exploration and scientific research upon which to build a regional identity. Although China was an early adherent to the landmark 1920 Svalbard (or Spitsbergen) Treaty, signing the agreement in 1925 (Gao 2012), extensive circumpolar research did not follow until the 1990s, when Beijing hastened to build competence in the areas of research and scientific diplomacy at both poles.

Some Arctic governments have expressed concerns about China seeking to unilaterally challenge the political status quo in the region. These views have been folded into the larger question of perceived Chinese 'assertiveness' in other parts of the world, including in the South China Sea, the East China Sea and the greater Indo-Pacific region, under the current government of President Xi Jinping (Johnston 2013; Shambaugh 2013: 269-306). Beijing's developing interest in the Arctic, especially before being 
admitted to the Arctic Council, the primary high-level governmental forum in the region, as an observer in 2013, sparked further apprehension in some policy quarters that a strategy of revisionism in the region was being tacitly but steadily constructed by Beijing (Kraska 2011: 257, 258; Le Mière and Mazo 2013: 130-133; Robinson 2013; Struzik 2013).

This was notably the case with Canada and Russia, Arctic countries traditionally the most wary about protecting their polar jurisdiction. In Ottawa, the government of Prime Minister Stephen Harper (2006-2015) was known for its firm stance on Arctic sovereignty amid concerns about growing Chinese regional interest. Incidents such as a backlash over unfounded reports of a potential Chinese scientific research station in Nunavut and the controversial barring of Chinese news agencies from Harper's Arctic tour in mid-2014 further soured the possibility of greater bilateral regional cooperation at that time (Galloway 2011; CBC News/Associated Press 2014; Vanderklippe 2015). Russia was initially opposed to China assuming an expanded Arctic presence, including observer status in the Arctic Council, on the grounds that Beijing's interests in the region were only economic, and that Beijing within the Council would upset the power balance of that regime. Both Canada and Russia were also worried about whether Beijing harboured differing views on the legal status of emerging northern sea routes (Chernenko 2013; Graczyk and Koivurova 2014: 5; Røseth 2014). Concerns about being seen as a regional 'gate-crasher' undoubtedly coloured Beijing's approach to circumpolar affairs in a measured, conservative manner. As one Xinhua commentary noted shortly before China obtained observer status in the Arctic Council, the country had to face accusations that its interests in the region were solely to obtain resources and establish a military presence, a stance denigrated in the Chinese press as 'misunderstanding and making mischief' (Chen 2013).

Beijing has sought to develop an information network to better define and deepen its Arctic policies by advocating increased regional cooperation, especially in scientific areas but also more frequently in the form of economic joint ventures, with Arctic governments and firms. Russia and Iceland have, so far, been especially noteworthy examples of these policies. China is not alone in Asia as a non-Arctic state seeking greater Arctic engagement, and must be mindful of losing diplomatic ground in the region to other Asian governments, particularly Japan and the Republic of Korea. When Beijing was invited to become an observer in the Arctic Council it was joined by India, Japan, the Republic of Korea and Singapore, whose governments have also intensified their Arctic engagement plans in various ways. Tokyo's first Arctic governmental white paper in October 2015 included a short section on why Arctic resources and transit routes were linked to Japanese national security (Headquarters for Ocean Policy 2015; Lanteigne 2015b). Beijing especially seeks to avoid overt competition among other non-Arctic states for regional influence, as evidenced by China's growing willingness to engage Tokyo and Seoul on trilateral talks regarding Arctic scientific cooperation.

Finally, Beijing is limited in its ability to engage the Arctic on a multilateral level. The Arctic Council is a small forum operating by consensus, with only eight members along with permanent participants from indigenous peoples' organisations and twelve non-voting observer states (including China) with more potential governmental observers already queuing for potential admission in 2017. Twenty other actors, representing intergovernmental, interparliamentary and non-governmental organisations, also sit as observers. Many internationallevel agreements, including the 1982 United Nations Convention on the Law of the Sea (UNCLOS) and the International Maritime Authority (IMO), are also heavily involved in developing Arctic governance and strategic questions. Yet the comparatively embryonic regional-level institutional development of the Arctic, coupled with the rapidly growing interest of non-Arctic states and actors led by Beijing in engaging the region, has prompted the question of the degree to which the Arctic should be considered an international concern as opposed to a regional one.

While several legal and institutional frameworks, including UNCLOS, serve to regulate current and future international activities in the Arctic Ocean, the question of norms is another matter. Norms in international relations are commonly defined as 'collective expectations for the proper behaviour of actors with a given identity', which can often define actor behaviour and/or prescribe and regulate actor conduct (Katzenstein 1996: 5). It is within the parameters of Arctic norms that Beijing has been seeking to manoeuvre and develop its policies of regional engagement. China has become more comfortable, as a rising great power, with developing international norms along with new regimes, with the Asia Infrastructure Investment Bank (AIIB) and the 'Belt and Road Initiative' (yidai yilu guihua 一带一路规划) developed by President $\mathrm{Xi}$ since 2013, as recent examples. Yet, for Beijing to become a 'norm-maker' in the Arctic, unilaterally pushing for a redefinition of the region's identity to allow China to formalise its growing Arctic presence is not viable, given the aforementioned obstacles. As well, Beijing's Arctic policy has been guided by concerns that China would otherwise be perceived in the region as a revisionist actor, or worse, a 'norm-shaker', and subject to tacit or direct exclusion as the Arctic becomes subject to more economic, and perhaps strategic, activities.

However, reluctant to be marginalised as a result of an underdeveloped presence within a rapidly changing political and strategic mosaic in the Arctic, Beijing has instead taken on the identity of a 'norm entrepreneur'. China is 'selling' the idea of an Arctic developed and structured via partnerships and regimes between Arctic and non-Arctic actors for mutual benefit, while ensuring that China's own interests in the region can be enhanced without triggering opposing policies among the Arctic states, especially Washington and Moscow. To succeed in 
this endeavour, Beijing has approached Arctic diplomacy on several levels, from the local to the regional.

To accomplish these goals, Beijing must navigate several potential challenges, including the difficult diplomatic relations between Russia and the USA and its European allies, the potential for a resource scramble in the region, and China's own incomplete Arctic policies and strategies and the need for further 'on the ground' information. It is apparent that Beijing wishes to formalise its Arctic identity, becoming a participant in future debates and developments surrounding regional governance as befits its great power status. However, it seeks to do so, at least for the near term, with a persona more akin to that of a salesperson than an advocate.

\section{'Can I interest you in a norm?' Beijing's path to an Arctic identity}

The speed at which the Arctic attracted the attention of much of the international community has equalled the rate at which more of the lands and seas in the Arctic Ocean region have become available as a result of retreating ice. It was announced in March 2016 that Arctic ice had reached a record low maximum for the second consecutive year, and that air temperatures throughout the region that winter were on average $2-6^{\circ} \mathrm{C}$ above normal, while in September 2015 it was reported that the Arctic had experienced the fourth smallest minimum ice extent that summer. Concerns have also increased about this having a cumulative effect in other parts of the region. Ice erosion, including the vast Greenland ice sheet, has led to predictions that an ice-free Arctic Ocean may become a reality in the coming decades (NSIDC 2015; 2016; Liu and others 2016). The stage has been set for debates not only about future environmental effects on Arctic states and peoples but also the issues and opportunities the warming circumpolar north presents to non-Arctic states and interests in a variety of areas.

China has sought to elucidate its Arctic interests in the past decade, but has needed to do so both under time pressures, to avoid being excluded from future political and economic benefits of an Arctic presence, and within an atmosphere of international scrutiny as a side-effect of being the largest non-Arctic state to develop a circumpolar northern strategy. The magnitude of the problem was illustrated when China's then-Assistant Minister of Foreign Affairs, Hu Zhengyue, sought to stifle speculation about his country's developing Arctic agenda by stating in 2009 that Beijing did not have one (Ning 2009). Such passivity is now no longer an option given China's developing great power status and its diversified Arctic interests.

One of the most visible aspects of China's modern foreign policy, especially under the government of $\mathrm{Xi}$ Jinping, has been a steady transition from 'norm-taker' to 'norm-maker' in the Asia-Pacific region and in many other parts of the world, as a product of the growth of Chinese power and evolution into great power status (Checkel 2001; Björkdahl 2005). This has been especially evident in the area of institutions. During the first few decades of the country's opening to global regimes, a common approach was an acceptance of rules and norms ("normtaking') in exchange for the benefits of compliance which included tangible goods and information and an improved identity. However, since the turn of the century China has moved towards building and backing new institutions better reflecting its interests ('norm-making'). Examples include financial institutions such as the AIIB and the New Development Bank, security regimes such as the Shanghai Cooperation Organisation and the Conference on Interaction and Confidence-Building in Asia, and 'hub and spoke' regional organisations designed to position Beijing as an alternative partner to other great powers, with one example being the Forum on China-Africa Cooperation (Vickers 2013; Lanteigne 2016: 73-99).

In the case of the Arctic, however, neither 'normmaking' nor '-taking' is a viable option for China. To seek norm-making status in the Arctic, given its lack of polar geography and still-underdeveloped regional identity, would be to invite the label of 'gate-crasher', with Beijing probably facing some sort of soft power balancing against it, both from Arctic states and possibly other nonArctic actors. While further Arctic engagement would not stop for China, it would become considerably more difficult. To accept the position of a norm-taker would be equally precarious, given that the country would risk being excluded from the Arctic's rapid political, economic and possibly strategic changes. Should it take an approach to the region that is too passive, Beijing would risk losing influence in its development, especially problematic if, as a result of international political pressures on the circumpolar north, new regimes were created in order to better balance the policies of Arctic and non-Arctic states. A norm-taker policy for Beijing would also be vulnerable to a greater securitisation of the Arctic, should deteriorating relations between Russia and the West spill over into far northern affairs. Despite ongoing attempts to compartmentalise regional diplomacy by the Arctic Eight, separating regional issues, such as discord over the Ukraine crisis, from those outside with several Arctic nations augmenting or debating their strategic policies in the region, there is still the possibility of zero-sum policies which would leave non-Arctic states such as China excluded.

Faced with these two unsatisfactory options, Beijing is seeking to apply norm entrepreneurship in the Arctic as an acceptable, and possibly very lucrative, alternative. The conventional description of a norm entrepreneur is a state, or other actor, which invites other actors to participate in a re-evaluation of a particular concept or policy, for example humanitarian intervention, through dialogue in the hope of creating a different norm, one more acceptable to the entrepreneur. This is commonly undertaken through various forms of persuasion as well as the 'socialisation' of other states in the hope of creating a 'norm cascade' of other states and actors accepting the new norm, and then finally a fait accompli, meaning that the norm is 
taken for granted and not subject to any serious challenge or revisionism (Finnemore and Sikkink 1998; Linklater and Suganami 2006: 143, 144). The process of norm entrepreneurship, defined as 'a deliberate and sustained campaign to create, change or maintain shared social norms and inter-subjective practices to enable political cooperation' (Carr and Baldino 2015: 33), has commonly been studied through the lens of small and medium power diplomacy, notably the Nordic region, or via patterns of 'norm diffusion' carried out by international organisations seeking to create global-level changes in state and other actor behaviour (Finnemore 1993; Ingebritsen 2002). Great powers, such as the USA and China, are more frequently associated with unilateral norm-making as a product of their size and influence.

That said, it is argued that China has developed the identity of a norm entrepreneur in the Arctic, seeking to advocate, or 'sell', the norm which suggests, since the Arctic has grown as an international concern in several areas, political, economic, environmental and strategic, to the degree that Arctic governments and other actors will no longer be able to address these changes by themselves, non-Arctic governments and actors should have a greater say in these areas. The Arctic should, therefore, be more accurately perceived as an international concern, as opposed to a strictly regional one. The secondary norm being advanced is that China, a great power and the largest of the non-Arctic states, is in a unique position to confront these changes, in partnership with other Arctic and non-Arctic actors. While Beijing attempts to avoid the impression it seeks to overturn current socio-political rules and norms in the Arctic, it is attempting to 'frame' (Payne 2001) current debates over how climate changes in the region will affect politics, economics, security and other related areas, best addressed through more direct participation by non-Arctic states offering many potentially significant contributions.

Given the increasing global awareness of the Arctic due to regional climate change, as well as concerns about the political impact of these effects, the atmosphere surrounding China's attempts at norm entrepreneurship is congenial. Beijing has expressed no wish to directly challenge either international laws in the Arctic, nor existing regimes such as the Arctic Council, but is seeking to draw attention to the concept of the circumpolar north as an international space. In order to 'sell' this norm, China has embarked on a series of bilateral and multilateral initiatives to establish itself primarily as an essential regional partner, while presenting its case for non-Arctic states to play a greater role as the Arctic opens up, politically and economically. Beijing has deployed a variety of diplomatic and policy tools to achieve these goals.

\section{Musings of a near-Arctic state: what China seeks in the north}

China is not alone as a non-Arctic state seeking a deeper Arctic identity. Several governments, especially in western Europe and East Asia, have also identified the far northern regions as an emerging foreign policy interest. Unlike other observers in the Arctic Council, such as the UK, Italy, Japan and the Republic of Korea, Beijing has yet to publish a comprehensive Arctic policy paper, although in late 2015 it was stated that such a document was in preparation (PRC Foreign Affairs official, personal communication, October 2015) and will inevitably be the subject of much scrutiny, given China's great power status and considerable attention given to the country's Arctic policies in the past decade.

During the annual Arctic Circle conference in Reykjavík in October 2015, Chinese Vice-Foreign Minister Zhang Ming presented a six-point statement of Beijing's Arctic policies. These included the need for future exploration and knowledge about the region, the protection and 'rational use' of the Arctic, respect for the inherent rights of Arctic states and indigenous peoples, respect for the rights of non-Arctic states and the international community, creation of a 'multi-tiered cooperation framework for win-win results' in the region, and the need for continued observance of relevant international law and institutions, including UNCLOS and the Svalbard Treaty (Zhang 2015). While the first three points are standard policies for non-Arctic states seeking engagement with the Arctic Council and its membership in circumpolar affairs, the latter three points form much of the foundation for Beijing's norm entrepreneurship which further formalises the international aspects of the region and, not tangentially, China as an important Arctic actor.

Beijing's Arctic interests include much overlap as Chinese policies in the region evolve. First, and by far the least politically difficult, has been scientific diplomacy, specifically China's interest in examining how changing Arctic conditions are directly impacting the country from an environmental and socio-economic standpoint. Second, Beijing wishes to participate in the economic development of the Arctic in the form of potential oil and gas extraction in the polar seas and also mining operations as conditions increasingly permit. Other economic benefits of the Arctic revolve around the increased use of regional sea routes which are becoming sufficiently ice-free in summer months to permit maritime transit faster than by using the traditional Indian Ocean routes. China's interests centre primarily on the Northern Sea Route (NSR) north of Siberia, which connects Novaya Zemlya in the east and the Bering Strait to the west (Blunden 2012). The NSR is a developing concern given the potential of Chinese (as well as Japanese and Korean) vessels travelling to northern Europe. However, Beijing has also expressed growing interest in the Northwest Passage (NWP) in Arctic Canada for transits between the north Pacific and the North American east coast. Third, China also seeks an expanded role in regime development in the Arctic, via the Arctic Council and other governmental and subgovernmental organisations, but also to be 'in place' should new circumpolar regimes appear as a result of the growing political and economic role of the Arctic in global 
affairs. It can be argued that while the Arctic is hardly terra (or mare) nullius with several regional and international regimes overseeing Arctic affairs, whether these regimes will be able to rebuff pressures from non-Arctic actors remains to be seen. Future variables which may further prompt a rethinking of Arctic institutions include energy and commodity price increases, an overflow into Arctic affairs of diplomatic tensions between the West and Russia, and disputes over sovereignty in regions such as the Lomonosov Ridge in the central Arctic Ocean. As well, Beijing will remain highly sensitive to any attempts by Arctic governments to assert exclusive sovereignty and treat regional 'goods' as the sole property of the eight circumpolar states.

Chinese policymakers and specialists have argued that while the country is not an Arctic nation, environmental changes in the circumpolar north have affected China's climate in recent years. Over the past decade, research on climate change in China has accelerated considerably (Stensdal 2014), with the Arctic often included as a case study. This rationale prompted references in Chinese scholarly papers and media to the country being a 'nearArctic state' (jin beiji guojia 近北极国家) (SIPRI 2012; Xinhua 2013; People's Daily 2013). Vice-Minister Zhang also used that phrase in his 2015 six-point speech, suggesting a more formalised degree of acceptance of the concepts. Some detractors who feared Beijing was attempting to create an artificial Arctic identity and become a 'gate-crasher' pointed to these terms as evidence, an impression not helped by the fact that this debate took place just prior to the collapse of fossil fuel prices in 2014, when there was much debate about an 'inexorable' Arctic resource scramble (Beck 2014; Vanderklippe 2014).

Chinese actors responded to questions about its 'nearArctic' identity insisting the phrase referred less to geography than to the degree to which Arctic events had an impact on China, and vice versa, given the country's status as a great power (Wang 2013; Yang and others 2013). China has, therefore, been seeking to add to its identity as a 'near-Arctic state' by augmenting its regional scientific credentials. The country's Yellow River scientific research station (Huanghe zhan 黄河站) at Ny-Ålesund on the Norwegian islands of Svalbard was opened in July 2004, and the country operates an icebreaking vessel, the Xuelong (雪龙, 'Snow Dragon'), for missions near both poles, with a second icebreaker, priced at approximately 153 million USD, scheduled to be completed in 2018. During Xuelong's 2015-2016 expedition to Antarctica, a new fixed-wing aircraft designed specifically for polar flights, Xueying-601 (雪鹰-601, 'Snow Eagle 601') was tested for the first time (China Daily 2004; CAA 2016; Lu and Zhong 2016; Xinhua 2016).

Structurally, polar expeditions are organised by the Chinese Arctic and Antarctic Administration (CAA) under the aegis of China's State Oceanic Administration (SOA), which is itself subordinate to the Ministry of Land and Resources. The Polar Research Institute of China (PRIC) has served as a hub for Chinese polar studies since
1989, although the organisation's small Strategic Studies Division, which oversees social sciences in the polar region, has only been in place since 2006 (http://www. pric.org.cn accessed, 20 September 2015). As well, the China-Nordic Arctic Research Council (CNARC), created in 2013, coordinates Arctic research between China and the European Arctic region, evolving as a major 'Track II' organisation linking Chinese and Arctic expertise on a sub-governmental level.

China has also sought Arctic partners for other research endeavours, such as the China-Iceland Joint Aurora Observatory, built at Kárhóll in northern Iceland and expected to open in late 2016 (Raspotnik 2016). Russia has also factored into potential initiatives for bilateral scientific cooperation, given warm Sino-Russian political relations and Chinese interest in potential co-development projects in Siberia and the Russian far east. One example was an announcement in February 2016 by the SOA that it was seeking to collaborate with Moscow in an Arctic exploration mission later that year, and there was discussion regarding Chinese scientific cooperation with Canada, possibly via the planned High Arctic Research Station in Cambridge Bay, Nunavut (CBC News 2015; Tîrnoveanu 2016; Xu 2016).

All of these current and potential projects serve to address gaps in China's knowledge of the Arctic, in terms of geography and environment but also economics and sociology. Science diplomacy is also perceived as a means for China to raise its profile in the Arctic as partner and problem-solver while reinforcing the positive roles that non-Arctic states can play in regional affairs. The success of China's norm entrepreneurship in the Arctic will depend on the ability of the country to develop an identity as an essential partner for regional knowledge gathering and sharing, and this facet of Chinese Arctic diplomacy will probably remain a priority, not only in the scientific realm but in the areas of economics and politics.

\section{Economics and transit diplomacy: dodging the storms}

Until the drop in global commodity prices during 2014 2015, there was widespread speculation that the Arctic would be the site of the next great competition for economic power as a result of larger amounts of resources becoming more readily available for exploitation (Fairhall 2010, 15-26; Borgerson 2013). This speculation was fuelled by the now-notorious 2008 report from the United States Geological Survey stating the Arctic may hold $13 \%$ of undiscovered global petroleum supplies (90 billion barrels) and approximately $30 \%$ of the world's undiscovered natural gas $\left(47.3 \mathrm{~m}^{3}\right)$ (Bird and others 2008; Gautier and others 2009). For China, increasingly dependent upon fossil fuel imports since its economic take-off in the 1990 s, the prospect of such resources in a politically stable region was a major impetus for more serious study of the Arctic. A senior representative of the China National Petroleum Corporation, speaking at the annual Arctic 
Frontiers conference in Tromsø, noted that his firm stood ready to participate in regional fossil fuel extraction and that developing Arctic resources required the "joint efforts of all countries' (China Daily/Xinhua 2015). Speculation about an Arctic boom, however, was quickly squelched by the commodity crash (Koyanagi 2016), which rendered local large-scale resource extraction, via drilling and mining, financially nonviable. However, given the cyclical rise and fall of commodities markets over the past century, there remains the question of when resource prices will recover to the level where the Arctic will again be considered an attractive region for resource development.

Like other non-Arctic states, China is taking a longterm view of the economic potential of the Arctic Ocean, including in the area of resources. In May 2014, a 30-year Sino-Russian natural gas deal worth 400 billion USD was struck between China National Petroleum Corporation and the Russian energy firm Gazprom. Two Chinese banks also agreed to help finance the Yamal liquefied natural gas (LNG) project in April 2016, and other Chinese institutions, including Beijing's 'Silk Road' sovereign wealth fund, are invested in the 27 billion USD project, which would see LNG being shipped to China and other parts of East Asia by 2017. In late 2013, the China National Offshore Oil Corporation obtained the rights, in partnership with Icelandic and Norwegian energy firms, to explore for oil and gas in the Dreki region of the north Atlantic (Gardiner 2013; Anishchuk 2014; Marson 2016), the first offshore drilling operation undertaken by a Chinese firm in the Arctic region. This has played a significant role in China's policies of ensuring its inclusion in future discussions and projects related to Arctic development.

The global commodities downturn has provided Beijing an opportunity to fine-tune a norm entrepreneurial approach. This is significant since Beijing has experienced the greatest degree of pushback in the realm of Arctic resource diplomacy. Concerns from other Arctic powers about China seeking to construct a regional identity for the purpose of far northern resource exploitation, along similar lines as perceived Chinese resource diplomacy in commodity-rich regions such as Africa or the Middle East, has produced a heightened sensitivity to a Chinese 'normshaker' policy in the Arctic. For example, in early 2012, the People's Liberation Army Navy Rear Admiral, Yin Zhuo, caused controversy when he reportedly described the Arctic as belonging 'to all the peoples around the world' and not to any specific country. However, subsequent reporting sometimes took the quote out of context, as the complete statement was: 'According to UNCLOS, the North Pole and its surrounding areas do not belong to any single country, and the common riches in the area belong to all the people in the world' (Chang 2010; China News Network 2010; Strader 2012).

Greenland (population 56,500) was the site of another infamous example of the pitfalls of current Chinese regional resource diplomacy. In 2009, Greenland received 'self-rule' from Denmark, with Copenhagen retaining oversight of defence and foreign affairs. Since that time, the Greenlandic government has sought stronger international ties, quietly exploring the option of eventual independence (Ackrén and Jakobsen 2015). The island is rich in mineral wealth, ranging from base and precious metals to gemstones to rare earth elements (REE), which are becoming more accessible as the ice sheet recedes. Several firms, including from China, have conducted surveys as a precursor to potential mining projects. One locale, Kvanefjeld/Kuannersuit is viewed as a site for future REE and uranium extraction, and in September 2016 it was announced that a Chengdu-based rare earths firm, Shenghe Resources Holding, had agreed to acquire $12.5 \%$ of shares, worth approximately 3.5 million USD, in Australia's Greenland Minerals and Energy, the company which is seeking to develop the Kvanefjeld area (Lajeunesse and Lackenbauer 2016: 88; News.com.au 2016).

Also, in 2012 reports appeared stating that an iron mine facility, worth potentially two billion USD, at Isua in western Greenland, with rights at the time held by a UK firm, would require thousands of Chinese labourers, leading to heated debates about logistics, Denmark's stance and potential interdiction, and even whether Beijing was seeking a permanent political presence on the island. In an unusual statement from the Chinese Foreign Ministry in March 2013, speculation about 'Chinese inroads into Greenland' was denigrated and included a declaration that no Chinese workers had been transferred there (Arctic Journal 2013; Breum and Chimnitz 2013; PRC Foreign Ministry 2013). Rights to the Isua site were sold in January 2015 to a Hong Kong firm, General Nice, but depressed iron prices called into question when and how the mine might actually open (Hornby and others 2015). This issue not only underscored the problem of China being termed an Arctic 'gate-crasher', but also the utility of taking a norm entrepreneurial approach to Arctic development. In this case, it would be difficult for Greenland itself to develop a single mine without considerable outside financing, materiel and labour. China would be foremost among non-Arctic states to provide these resources, but must avoid getting embroiled in political concerns, including the question of Greenlandic independence, while approaching such partnerships.

In addition to resources, the opportunities for expanded use of Arctic trade routes has factored into Chinese economic considerations in the region. As well as the NSR and the NWP, another route of interest to China, as well as to other parts of Asia, has been the Northern Pacific Great Circle Route, which runs from northeast Asia via the Aleutian Islands to the Canadian and American western coasts. There is also a potential 'Central Arctic Route', which could become a reality in the coming decades if the Arctic ice cap disappears completely during summer months (Smith and Stephenson 2013; Bennett 2014: 76). In mid-2012, Xuelong transited the Northeast Passage and the central Arctic Ocean in a trial run (Yu and others 2014). Considering the significance of trade on the modern Chinese economy, Beijing can ill-afford to 
dismiss the potential benefits of these emerging sea routes. Nonetheless the political implications and infrastructure associated with these routes argue for a moderate approach to future Chinese usage, especially in the case of the NWP and any future paths through the central Arctic (Zhang and others 2016).

Key to these plans were the Arctic missions of the icebreaker Xuelong, and the transits of the NSR by the modified cargo vessel Yongsheng (永盛), owned by China's Ocean Shipping Company, Cosco. The test vessel's first transit took place in August-September 2013 when it travelled from Dalian to Rotterdam in thirty-three days, approximately two weeks shorter than using the traditional Indian Ocean route. In mid-2015, Yongsheng sailed from Dalian to Varberg, Sweden, and back via the NSR (MacDonald-Gibson 2013; Lanteigne 2015a). In the wake of both successful trials, Cosco expressed hopes that regular usage of the NSR by Chinese cargo ships could take place. It was also suggested by the head of the PRIC in March 2013 that 5-15\% of Chinese international trade could make use of the Arctic routes by 2020, a figure representing an estimated 600 billion USD (Doyle 2013; Paris and Chu 2015). Use of the NSR by China and other Asian economies for Asia-Europe shipping is uncertain, as several obstacles remain, ranging from difficult weather and floating ice hazards to insurance costs and other economic considerations. In 2013, 71 ships used the NSR for shipping, but that figure dropped to 31 in 2014 and only 18 in 2015 (Northern Sea Route Information Office http://www.arctic-lio.com/nsr_transits, accessed 5 March 2016). Nonetheless, the possibility of extensive use of the NSR by China and other northeast Asian economies may galvanise port and other infrastructure development along the route. The NSR may even emerge as a complement, if not a component, of future Chinese 'belt and road' trade initiatives.

In April 2016, Beijing began to create a framework for the possible use of the NWP for shipping when China's Maritime Safety Administration published an Arctic navigation guide which described the conditions and geography of the Canadian Arctic Archipelago and its potential use by Chinese vessels, following up on a similar guide to the NSR region published in 2014. A more formal announcement was issued by Beijing indicating Chinese shipping vessels may also use the NWP in the future, as a means of avoiding the Panama Canal and reducing transit time to the North American east coast (Peng 2016). Despite the announcement that use of the NWP by Chinese ships would be for economic purposes only, the statement created a political controversy, given that the legal status of the passage is disputed, specifically by Canada and the USA. The former considers the passage, made up of seven specific routes between the islands in question, to be Canadian internal waters, while the latter views them as international waters, a difference which created a point of diplomatic contention for decades. After 1988, when an Arctic cooperation agreement was signed between Ottawa and Washington (Rothwell 1993; Côté and Dufresne
2008), a tacit 'agree to disagree' stance was maintained between the two governments, aided by the fact that until recently the NWP was considered to have little commercial appeal. With that change, the possibilities for shipping in the region became more attractive.

The Chinese Foreign Affairs Ministry's statement accompanying the NWP announcement carefully avoided an opinion on the sovereignty issue, with the spokesperson ambiguously noting that 'Canada has imposed some restrictions on the use of the Northwest Passage, asking foreign vessels to inform the Canadian side and get permission before entering or crossing its exclusive economic zone and territorial waters. The Chinese side will make appropriate decisions by taking into account various factors' (Foreign Ministry PRC 2016) According to a representative from Global Affairs Canada, there were no previous bilateral discussions on the subject of Chinese use of the NWP prior to the announcement from Beijing, and the Canadian stance on the waterways remained unchanged, specifically that 'all waters of the Canadian Arctic Archipelago, including the various waterways known as the "Northwest Passage," are internal waters of Canada and we retain the right to regulate them just as we would any land territory,' with no inherent right of transit or innocent passage by an outside party (Global Affairs Canada official, personal communication, April 2016). It remains unclear as to when China would be seeking to send its first ship through the NWP waterways, or how potential consultations between China and Canada, as well as the USA since use of the NWP would also involve Alaskan waters, might unfold.

A signal of sorts was sent by Beijing to the USA in September 2015, relating to Chinese intentions regarding future sea transits in the Arctic, when five Chinese People's Liberation Army Navy vessels, following joint exercises with Russian Navy ships in the north Pacific, transited the Bering Sea off the coast of Alaska without informing Washington (Stewart 2015). Although the transit was legal under the rules of 'innocent passage', the event took place when President Obama was in the state participating in an international Arctic conference, suggesting the timing of the event was probably designed to remind Washington of Beijing's ongoing Arctic interests while also laying the framework for future regional maritime activities. As China's maritime capabilities become more 'blue water' (deep ocean) in character, another facet of Beijing's norm entrepreneurship is to advance the idea that Chinese ships should have a commonplace, even mundane, presence in the Arctic Ocean.

With Beijing seeking to expand the use of maritime trade both through the belt and road initiative and probably via Arctic routes as they become more practicable, China is seeking to ensure a fait accompli in which Chinese vessels are permitted peaceful transits through the waterways in the future. Beijing will, therefore, have to promote the Arctic as a region of peaceful (and profitable) navigation, while participating in objectives, such as the Polar Code, which enters into force in January 2017, 
to regulate and ensure transit safety (Liu 2016). The prospect of greater Arctic militarisation, while remote, is not an impossibility given the deteriorated strategic relationship between Moscow and Washington and its NATO allies. For example, there has been a steady increase in incidents involving Russian military aircraft probing NATO airspace, including in the Arctic, while the USA has expressed concerns about a growing Russian rearmament in the Arctic and north Atlantic. This was evidenced by an agreement between Reykjavík and Washington in early 2016 to reopen military facilities in Keflavík, Iceland, in response to increased air and sea activities by the Russian military, although the Iceland Foreign Ministry stressed the agreement would be more focussed on ensuring civil security (Bittner 2016; Winger and Petursson 2016). Any trend towards regional militarisation would not only affect the future of civilian shipping in the region but would also deprive non-Arctic states, such as China, of the ability to make use of Arctic routes, a scenario Beijing wishes to avoid as it conducts its norm entrepreneurship in the region.

\section{China and Arctic institutions: above, below and beyond?}

Currently, the Arctic Council, which celebrated its 20th anniversary in 2016, remains the primary institution overseeing regional affairs, thus explaining Beijing's enthusiasm for joining its roster of observers as its Arctic interests grew. However, it remains an open question as to whether the organisation can continue in its current 'soft law' format as the Arctic assumes a growing international profile with more states seeking engagement with it. Among the governments that are likely to be seeking formal observer status at the next council ministerial meeting in 2017 are Greece, Mongolia and Switzerland, as well as the European Union, a perennial also-ran. There remains the issue of whether the council will be required to 'deepen' its interests, as it currently has a limited mandate, which for example does not address military security issues, as specified in the Ottawa Declaration, the council's founding document (Arctic Council 1996), and does not have a dispute settlement mechanism.

As the Arctic becomes subject to intensified globalisation, debate has begun as to whether the council should become more formalised. Among the options suggested is the creation of a formal Arctic treaty, an idea which predated the council, possibly using the Antarctic Treaty as a baseline (Koivurova 2008; Hasanat 2013). Such an option would deepen the institutional mechanisms of Arctic governance and allow for a greater degree of participation by non-Arctic states. However, a treaty system remains too unpopular with the council membership, especially Canada and Russia which have been especially sensitive to their northern sovereignty, to be a short-term solution to the Council's shortcomings (Graczyk and Koiurova 2014). Since China and other new observers were admitted in 2013, the organisation has sought instead to clarify the relationship between the council and its observers. An amended and expanded council observer manual was approved at a senior Arctic officials meeting in Anchorage, Alaska in October 2015, incorporating calls for observers to participate more fully in council affairs, including in the organisation's working groups, and to provide logistic and financial support to council projects (Knecht 2016). It remains to be seen, however, whether these upgrades will be sufficient to address the ongoing Arctic globalisation questions, especially with other potential observers waiting for admission.

At present, Beijing is content to play the role of observer in the organisation, and it is highly likely that when China's status is subject to review in 2017 as per the council's procedural rules, Beijing will express its commitment to the organisation and a desire to remain an observer. Yet, there is the question of whether that level of satisfaction can be sustained if the Arctic begins to rapidly open up to further political and economic activity and the list of observers becomes longer. There is no provision in the council's rules to allow for the promotion of an actor from observer to member, especially in the case of a state without an Arctic border. Should the Arctic continue to globalise, with greater participation in regional political, economic, communication, transportation and scientific affairs by non-Arctic states in the region, it may become difficult to sustain the current Arctic Council model, especially in regards to the subject of voting rights. Would different tiers of observers be created? Would nonArctic states be given voting rights on certain issues? Will a de facto Arctic treaty appear regardless of regional misgivings? Whatever the answers to these questions, China will be at the centre of the process. It is in this area where Beijing as a norm entrepreneur is also becoming more visible.

As contained in Vice-Minister Zhang's six-point Arctic statement, a 'multi-tiered' network of Arctic institutions should be developed to ensure the most effective forms of regional governance. It is clear that should new forms of regional institutions appear in the Arctic, Beijing wishes to ensure that it has a voice within them. One example of new regional institutions which would not be in China's interests is the loosely defined 'Arctic Five' (A5), consisting of the Arctic Ocean's littoral states (Canada, Denmark, Norway, Russia, USA). It was this group which produced the 2008 Ilulissat Declaration, calling for greater coordination among the A5 on legal affairs relevant to the Arctic Ocean. Not only did this agreement draw concern from the three council members left outside the process, but the Declaration may have further pushed various nonArctic states, including China, to enter the council as observers to discourage a 'locking up' of the region (Dodds 2013; Wilson 2016). Even among the A5, however, there is disagreement over certain aspects of Arctic sovereignty and strategy, as evidenced both by the Russian rifts with the West, as well as the overlapping maritime claims within the central Arctic Ocean outside of the littoral states' maritime jurisdiction, a space colloquially referred 
to as the 'doughnut hole'. Specifically, Canada, Denmark (via Greenland) and Russia have competing claims to the Lomonosov Ridge and other features in the central Arctic based on differing interpretations of their continental shelves, a dispute which could have considerable future ramifications in regards to both shipping and resources (RT.com 2016).

As well, the lack of security mechanisms specifically designed for the Arctic is generating concern in parts of the region as an unsustainable situation. Although the Arctic has certainly seen securitisation in the past, especially as the northernmost arena for the cold war-era standoff between NATO and the Warsaw Pact, questions have appeared not only about traditional security concerns but also non-traditional issues such as environmental, economic, energy and human security in addition to pressing concerns about civil emergencies, such as the safety of civilian maritime traffic in newly opened sea routes. The Arctic, which has been described as a case of 'messy governance', has been open to more flexible forms of governance in the strategic realm but there remains the question of whether the current institutions in the region can address these increasingly varied strategic concerns (Bailes 2016). For example, in a May 2016 Danish government review of foreign and security affairs, a specific call was made for an Arctic security forum in light of both Russian militarisation in the region and the need for greater confidence building among Arctic governments (Government of Denmark 2016). It was unclear from the statement as to what role, if any, nonArctic states would play in such an initiative, but should such a security forum take shape it is doubtful that China, along with many other Arctic Council observers, would accept a position on the sidelines, given their developing economic and political interests in the region.

It is in this growing atmosphere of institutional uncertainty in the Arctic where Beijing has been seeking to further develop its 'near-Arctic state' identity and underscore its role as an essential partner in regional affairs by seeking to tacitly advertise its unique role in the region as compared with other observer governments, given its size and power. As one Beijing-based area specialist noted in a 2013 paper, China is in a distinct position to act as a conduit for dialogue between Arctic and non-Arctic states (Tang 2013). During the period leading to China's admittance as an observer in the Arctic Council, the country was active not only in local scientific efforts but also engaging other key institutions, such as the IMO as well as regional organisations, and supporting institutions that represent Arctic indigenous populations (Beijing voted for the 2007 UN Declaration on the Rights of Indigenous Peoples) and environmental concerns (UNOHR 2007; Ye 2014). Key to Beijing's norm entrepreneurship in the Arctic is the concept of China-aspartner for Arctic institutions large and small.

Chinese government officials have also continued to advance the idea that while there are numerous issues in the Arctic which are best addressed by local governments, there is a developing list of issues ranging from climate change to economic activities requiring the input of nonArctic actors. In a November 2012 speech in Stockholm to representatives of Arctic Council members and observers, then-Chinese Ambassador to Sweden, Lan Lijun, noted that 'some of the Arctic issues are trans-regional, such as climate change and international shipping, which involve the interests of non-Arctic states. Arctic states and nonArctic states share common interests in addressing transregional issues and should further their communication and cooperation' (Swedish Ministry of Foreign Affairs 2012). The six-point statement by Vice-Minister Zhang further formalised this view, and it is likely that a future Chinese government statement on the Arctic will seek to further codify the argument that new regional mechanisms could and should include Beijing for maximum efficacy.

China's Arctic diplomacy on a bilateral level also increased both before and after the country's observer status in the Arctic Council was granted. Among the most notable examples has been improved Sino-Danish diplomacy, evidenced by a state visit by outgoing Chinese leader Hu Jintao in June 2012 and a watershed official visit by Danish Queen Margrethe II to Beijing in April 2014 (PRC Foreign Ministry 2012, 2013). China's interest in developing economic links with Greenland has been a major impetus for warming relations between Beijing and Copenhagen. Iceland is also a Nordic state which has experienced closer Chinese ties, anchored by the 2013 Sino-Iceland free trade agreement (FTA), the first signed by Beijing with a European economy and completed despite several obstacles created by the island's financial meltdown five years earlier. After a period of uncertainty, the visit by then-Chinese Premier Wen Jiabao in April 2012 not only started the FTA process but also resulted in a memorandum of understanding between China's SOA and the Icelandic Foreign Ministry on joint maritime and Arctic scientific cooperation, including in the areas of climate change and marine monitoring (Lanteigne 2010; Iceland Ministry of Foreign Affairs 2012). Other economic and scientific agreements have further strengthened links, and prominent members of the Icelandic government, notably the country's thenpresident Ólafur Ragnar Grímsson, have been staunch proponents both of China-Iceland ties and greater Asian involvement in Arctic affairs (Goldenberg 2013).

The situation between China and Norway, however, has been much more problematic in the wake of the downgrading of diplomatic ties following the awarding of the Nobel Peace Prize to Chinese dissident Liu Xiaobo in 2010. High-level government-to-government communication was suspended after the incident, a situation which has adversely affected many policy areas, including Arctic cooperation (Lanteigne and Sverdrup-Thygeson 2016). However, Norway did not block Beijing's Arctic Council observer bid, and Chinese and Norwegian Arctic specialists regularly meet in Track II multilateral fora, including CNARC and Arctic Frontiers in Troms $\varnothing$. Nonetheless, the 
ongoing diplomatic freeze may present future challenges to Beijing's overall Arctic norm entrepreneurship on a bilateral level.

Arctic ties with Moscow will be another challenge since, to Beijing, all roads to the far north, figuratively and at times literally, run through Russia. This is especially the case in the area of shipping and the future use of the NSR, but also within the wider sense of China being regionally accepted as an Arctic player. As previously noted, Russia has been sensitive to non-Arctic state involvement in the region. In February 2015, as Russia was developing a stronger military presence in its Arctic lands, Minister of Defence Sergey Shoygu remarked that 'some developed countries that do not have direct access to the polar regions obstinately strive for the Arctic, taking certain political and military steps in that direction' (Zvezda 2015). However, in light of Moscow's post2014 diplomatic ostracism after the Ukraine crisis, China remains in an important position to partner Russia in several Arctic areas, including economic development projects such as at Yamal, infrastructure in the NSR regions and scientific cooperation (Bertelsen and Gallucci 2016; Saroka 2016). The Sino-Russian relationship will probably grow stronger, retaining the characteristics of a marriage of convenience rather than a regional alliance.

There have also been increasing signs that Beijing is willing to deepen its engagement with fellow non-Arctic states, including in northeast Asia as part of its multi-tiered policy engagement of the far north. In November 2015, President Xi and Japanese Prime Minister Shinzo Abe were hosted by South Korean President Park Geun-hye in Seoul in an effort to repair trilateral ties badly frayed by disputes over regional security, including disputed regions such as the East China Sea. The result was a joint declaration, including a call for a separate trilateral meeting on Arctic affairs. That meeting took place in April 2016, with senior Arctic officials from the three governments agreeing to regular dialogue and discussion of cooperation on scientific projects in the region (Republic of Korea Ministry of Foreign Affairs 2016). Although this area of trilateral cooperation remains at the discussion stage, the meeting demonstrated China's interest in furthering the concept of Asia-Arctic collaboration as well as Beijing's view that there are notable areas of Arctic policy that should involve non-Arctic states. Despite numerous policy differences in other areas, the three northeast Asian governments are in agreement on the requirement for the Arctic to be considered more of an international space, and so dialogue with Japan, the Republic of Korea and most likely other non-Arctic governments may further bolster China's increasing efforts at Arctic norm entrepreneurship.

\section{Conclusions: China closes the deal?}

As the Arctic continues to open up as a result of climate change, longstanding norms related to the region's politics, economics and even security are now under increased local and global scrutiny. China has stepped into this arena seeking to develop a norm which identifies the Arctic to a greater degree as an international space, not in terms of geography but rather in the areas of policy and law making, economic development, the environment and knowledge gathering. Beijing has identified the Arctic as being a growing foreign policy priority given its broadening global commitments and ongoing interest in expanding trade and economic partnerships. China is also wary of being excluded, tacitly or directly, from a region which is demonstrating greater potential to affect global affairs in a variety of ways. However, due to its non-Arctic geography, still-evolving Arctic identity and policies, and heightened sensitivity in western states and Russia about the overall trajectory of Chinese power, Beijing cannot be considered a unilateral norm-maker in the Arctic, and has therefore been prompted to develop alternative policies.

Through a series of multifaceted approaches and levels, China has instead sought to develop and project the norm of the 'ideal' Arctic as one of partnership between local and non-local actors on key regional issues it has deemed 'international' in nature and in scope. To accomplish this, Beijing has taken the distinct step of becoming a norm entrepreneur in the Arctic, 'selling' the idea of the region requiring a greater threshold of non-Arctic participation, especially by China, in order to remain stable and also to evolve and thrive. Beijing wishes to portray itself as a partner in developing circumpolar scientific and economic endeavours, while at the same time underscoring its opposition to being left out of new regional institutions and dialogues.

China's norm entrepreneurship in the Arctic is far from complete, and there remain many obstacles ahead. Within norm theory, it has long been argued that a certain threshold of state actors is required in order to successfully transmit a given norm, and it has also been demonstrated that international organisations often play a strong role in 'norm diffusion', meaning the spreading of a norm to a wide area and often on a global scale (Finnemore and Sikkink 1998; Acharya 2004: 242-244). In the case of China and the Arctic, Beijing must face both an array of state actors which are still grappling with the new geographical and political realities of the region, and in many cases retain concerns about their Arctic sovereignty, as well as a still weak institutional network in the Arctic which currently oversees growing concerns such as various areas of security and still does not adequately reflect the balance of interests between the local and the international. As with many cases of norm introduction and entrepreneurship, there is no guarantee that this endeavour will be universally accepted.

At the same time, there is the risk of 'norm regress', meaning an existing norm eroding due to a variety of factors (McKeown 2009). In this case, trigger events which may cause the erosion of the 'international space' Arctic norm include worsening relations between Russia and the west, accelerating a military build-up, making it more difficult for non-Arctic states to engage the region, 
a change in the global economy which boosts energy and commodity prices to the point where the Arctic becomes an arena for a 'scramble', and more difficult relations between China and the USA which could spill over into the far northern reaches. Although there are risks in China's norm entrepreneurship in the Arctic, this policy choice has, so far, proved effective in ensuring that the country remains at the forefront of current and probable future debates about Arctic governance and development as well as the role of norm entrepreneurs in the region.

\section{Acknowledgements}

This article is dedicated to the memory of Alyson Bailes. The author wishes to thank Rasmus Gjedss $\emptyset$ Bertelsen, Courtney J. Fung, Lynn Gardinier, Su Ping, Össur Skarphéðinsson, Ming Ming Shih and Wrenn Yennie Lindgren for their assistance with the researching of this work.

\section{References}

Acharya, A. 2004. How ideas spread: whose norms matter? Norm localisation and institutional change in Asian regionalism, International Organisation 58: 239-275.

Ackrén, M. and Jakobsen, U. 2015. Greenland as a selfgoverning sub-national territory in international relations: past, current and future perspectives. Polar Record 51(4): 404-412.

Anishchuk, A. 2014. As Putin looks east, China and Russia sign \$400-billion gas deal. Reuters 21 May 2014.

Arctic Council. 1996. Declaration on the establishment of the Arctic Council: joint communique of the governments of the Arctic countries on the establishment of the Arctic Council, 19 September 1996. Ottawa: Arctic Council. URL: https://oaarchive.arctic-council.org/bitstream/handle/ 11374/85/00_ottawa_decl_1996_signed\%20\%284\%29.pdf? sequence $=1$ \&isAllowed=y (accessed 31 July 2015).

Arctic Journal. 2013. Unions upset over Greenland's revised mining law. Arctic Journal 21 October 2013, URL: http://arcticjournal.com/oil-minerals/unions-upset-overgreenlands-revised-mining-law (accessed 17 December 2015).

Bailes, A. 2016. Security in the Arctic: definitions, challenges and solutions. In: Jakobsen, L. and N. Martin. (editors). The new Arctic governance. Oxford: Oxford University Press, 2016: 13-40.

Beck, A. 2014. China's strategy in the Arctic: a case of lawfare? The Polar Journal 4(2): 306-318.

Bennett, M.M. 2014. North by northeast: toward an Asia-Arctic region. Eurasian Geography and Economics 55(1): 71-93.

Bertelsen, R.G. and V. Gallucci. 2016. The return of China, postcold war Russia, and the Arctic: changes on land and at sea. Marine Policy 72: 240-245.

Bird, K.J., R.R. Charpentier, D.L. Gautier and others. 2008. Circum-Arctic resource appraisal: estimates of undiscovered oil and gas north of the Arctic Circle. United States Geological Survey (Fact sheet 2008-3049). URL: http://pubs.usgs.gov/ fs/2008/3049/fs2008-3049.pdf (accessed 17 April 2015).

Bittner, J. 2016. East vs. west in the Arctic Circle. The New York Times 28 April 2016.

Björkdahl, A. 2005. Norm-maker and norm-taker: exploring the normative influence of the EU in Macedonia. European Foreign Affairs Review 10(2): 257-278.
Blunden, M. 2012. Geopolitics and the northern sea route. International Affairs 88(1): 115-129.

Borger, J. 2016. Russian attack jets buzz US warship in riskiest encounter for years. The Guardian 13 April 2016.

Borgerson, S.G. 2013. The coming Arctic boom- as the ice melts, the region heats up. Foreign Affairs 76: 76-89.

Breum, M. and J. Chimnitz. 2013. No, Greenland does not belong to China. The New York Times 20 February 2013.

$C B C$ News. 2015. China seeks to establish northern Canadian research outpost. CBC News 24 March 2015, URL: http://www.cbc.ca/news/canada/north/china-seeks-toestablish-northern-canadian-research-outpost-1.3006806 (accessed 30 July 2015).

CBC News / Associated Press. 2014. Stephen Harper bans Chinese media from Arctic trip. CBC News/Associated Press 22 August, URL: http://www.cbc.ca/news/canada/north/ stephen-harper-bans-chinese-media-from-arctic-trip-1. 2744310 (accessed 8 September 2016).

Carr, A. and D. Baldino. 2015. An Indo-Pacific norm entrepreneur? Australia and defence diplomacy. Journal of the Indian Ocean Region 11(1): 30-47.

Chang, G.G. 2010. China's Arctic play. The Diplomat 9 March 2010. URL: http://thediplomat.com/2010/03/ chinas-arctic-play/ (accessed 18 March 2015).

Checkel, J.T. 2001. Why comply? Social learning and European identity change. International Organization 55(3): 553588.

Chen, Z. 2013. Arctic Council observer status guarantees China's legitimate rights. Xinhua 16 May. URL: http://news.xinhuanet. com/english/indepth/2013-05/16/c_132387742.htm (accessed 15 November 2015).

Chernenko, E. 2013. PoccRUSSIAN TEXT?ия ограничивает полярный круг [Russia restricts the Arctic Circle]. Kommersant 14 May 2013. URL: http://www.kommersant.ru/doc/ 2187097 (accessed 28 August 2016). $\mathrm{CH}$

China, Maritime Safety Administration. 2016. 人民网: 《北 极航行指南(西北航道) 2015》出版发行> [People's Daily Online: Arctic navigation guide (northwest passage) 2015 published]. People's Daily Online 19 April 2016. URL: http://www.msa.gov.cn/page/article.do?articleld= 385A6378-4A9D-426A-B6F4-3050B6D8149F (accessed 29 April 2016).

China News Network. 2010. 海军少将: 开发北冰洋 中国不 可 '缺位' [Rear Admiral: China cannot be 'absent' in developing the Arctic Ocean]. China News Network 5 March 2010. URL: http://www.chinanews.com/gn/news/2010/03-05/ 2154039.shtml (accessed 12 October 2015). CH

China, Arctic and Antarctic Research Administration. 2016. A brief introduction of $R / V$ Xuelong. URL: http://www.chinare. gov.cn/en/index.html?pid=stations\&st=xuelong (accessed 15 March 2016).

China, Polar Research Institute of China. 2016. URL: http://www. pric.org.cn (accessed 20 September 2015).

China, Foreign Ministry, 2012. President Hu Jintao arrives in Copenhagen for state visit to Denmark. 15 June 2012. Foreign Ministry of the People's Republic of China. URL: http://www.fmprc.gov.cn/mfa_eng/topics_665678/ phjtdsg20_665710/t942736.shtml (accessed 21 November 2015).

China, Foreign Ministry. 2013．2013年3月15日外交部发言 人华春䒯主持例行记者会, 2013-03-15, [Foreign Ministry Spokesperson Hua Chunying's Regular Press Conference on 15 March 2013], Ministry of Foreign Affairs of the People's Republic of China. URL: http://www.fmprc. gov.cn/web/fyrbt_673021/jzhsl_673025/t1021757.shtml (accessed 2 May 2016). 
China, Foreign Ministry. 2016. Foreign Ministry spokesperson Hua Chunying's regular press conference on 20 April 2016. Foreign Ministry of the People's Republic of China. URL: http://www.fmprc.gov.cn/mfa_eng/xwfw_665399/ s2510 665401/2511_665403/t1357177.shtml (accessed 21 April 2016).

Côté, F. and R. Dufresne. 2008. The Arctic: Canada's legal claims. 24 October 2008. Ottawa: Parliament of Canada. URL: http://www.lop.parl.gc.ca/content/lop/ researchpublications/prb0805-e.pdf (accessed 2 May 2016).

Denmark, Government. 2016. 'Dansk diplomatiog forsvar i enbrydningstid: Vejen frem for Danmarks interesser og værdier mod 2030 [Danish diplomacy and defence in times of change: the way forward for Danish interests and values to 2030]. May 2016. URL: http://um.dk/en/foreign-policy/ danish-defence-and-diplomacy-in-times-of-change (accessed 10 May 2016).

Dodds, K. 2013. The llulissat declaration (2008): the Arctic states, 'Law of the Sea' and Arctic Ocean. SAIS Review of International Affairs 33(2): 45-55.

Doyle, A. 2013. China plans first commercial trip through Arctic shortcut in 2013. Reuters 12 March 2013.

Fairhall, D. 2010. Cold front: conflict ahead in Arctic waters. Berkeley: Counterpoint.

Finnemore, M. 1993. International organizations as teachers of norms: the United Nations Educational, Scientific, and Cultural Organization and science policy. International Organisation 47(4): 565-597.

Finnemore, M. and K. Sikkink. 1998. International norm dynamics and political change, International Organization 52(4): 887-917.

Galloway, G. 2011. Harper stands firm on sovereignty as China eyes Arctic resources. Globe and Mail 29 August 2011. URL: http://www.theglobeandmail.com/news/ politics/ottawa-notebook/harper-stands-firm-on-sovereigntyas-china-eyes-arctic-resources/article616967/ (accessed 2 June 2016).

Gao, Z. 2012. Legal issues of MSR in the Arctic: a Chinese perspective. Arctic Science, International Law and Climate Change 235: 141-154.

Gardiner, B. 2013. Iceland aims to seize opportunities in oil exploration. The New York Times 1 October 2013.

Gautier, D.L., K.J. Bird, R.R. Charpentier and others. 2009. Assessment of undiscovered oil and gas in the Arctic. Science 324(5931): 1175-1179

Goldenberg, S. 2013. 'China should have a say in future of Arctic' Iceland president. The Guardian 16 April 2013. URL: http://www.theguardian.com/environment/2013/apr/16/ china-future-arctic-iceland (accessed 18 February 2016).

Graczyk, P. and T. Koiurova. 2014. A new era in the Arctic Council's external relations? Broader consequences of the Nuuk observer rules for Arctic governance. Polar Record 50(3): 225-236.

Hasanat, M.W. 2013. Reforming the Arctic Council against increasing climate change challenges in the north. Michigan State International Law Review 22(1): 196-240.

Hornby, L., R. Milne and J. Wilson. 2015. Chinese group General Nice takes over Greenland mine. Financial Times 11 January 2015.

Iceland, Ministry of Foreign Affairs. 2012. Memorandum of understanding on cooperation in the field of marine and polar science and technology between the Chinese State Oceanic Administration and the Ministry of Foreign Affairs of Iceland, 20 April 2012.

Ingebritsen, C. 2002. Norm entrepreneurs: Scandinavia's role in world politics. Cooperation and Conflict 37(1): 11-23.
Japan, Headquarters for Ocean Policy, 2015. Japan's Arctic Policy - 16 October 2015. URL:http://library.arcticportal.org/ 1883/ (accessed 15 January 2016).

Johnston, A.I. 2013. How new and assertive is China's new assertiveness? International Security 37(4): 7-48.

Katzenstein, P.J. 1996. Introduction: alternative perspectives on national security. In: Katzenstein, P.J. (editor). The culture of national security: norms and identity in world politics. New York: Columbia University Press: 1-32.

Knecht, S. 2016. Procedural reform at the Arctic Council: the amended 2015 observer manual. Polar Record 52(5): 601605.

Koivurova, T. 2008. Alternatives for an Arctic treaty-evaluation and a new proposal. Review of European Community and International Environmental Law 17(1): 14-26.

Koyanagi, K. 2016. For commodities markets, the bad times are just beginning. Nikkei Asian Review 28 April 2016. URL: http://asia.nikkei.com/magazine/ 20160428-Commodities-crucible/On-the-Cover/

For-commodities-markets-the-bad-times-are-just-beginning (accessed 1 May 2016).

Korea, Ministry of Foreign Affairs. 2016. ROK, Japan and China to hold the first trilateral dialogue on Arctic cooperation. 25 April 2016. URL: http://www.mofa.go.kr/ webmodule/htsboard/template/read/engreadboard.jsp? type $\mid \mathrm{D}=12 \&$ boardid $=302 \&$ seqno $=316457$ (accessed 12 May 2016).

Kraska, J. 2011. The new Arctic geography and US strategy. In: Kraska, J. (editor). Arctic security in the age of climate change. Cambridge: Cambridge University Press: 256-257.

Lajeunesse, A. and P.W. Lackenbauer. 2016. Chinese mining interests in the Arctic. In: Berry, D.A., N. Bowles and H. Jones (editors). Governing the North American Arctic: sovereignty, security and institutions. Houndmills, UK and New York: Palgrave. 74-99.

Lanteigne, M. 2010. Northern exposure: cross-regionalism and the China-Iceland preferential trade negotiations. China Quarterly 202: 362-380.

Lanteigne, M. 2015a. There and back again. The Arctic Journal 19 August 2015. URL: http://arcticjournal.com/opinion/1761/ there-and-back-again (accessed 20 August 2015).

Lanteigne, M. 2015b. Japan's Arctic policy: the paper chase. The Arctic Journal 26 October 2015, URL: http://arcticjournal. com/opinion/1920/paper-chase (accessed 28 October 2015).

Lanteigne, M. 2016. Chinese foreign policy: an introduction ( $3^{\text {rd }}$ Edn.) New York and London: Routledge.

Lanteigne, M. and B. Sverdrup-Thygeson. 2016. Towards the thaw: seeking clarity in China-Norway relations. The Diplomat 16 January 2016. URL: http://thediplomat.com/2016/01/ towards-the-thaw-seeking-clarity-in-sino-norwegian-relations (accessed 17 January 2016).

Le Mière, C. and J. Mazo. 2013. Arctic opening, insecurity and opportunity. London and New York: IISS Routledge.

Li, X. 2014. Danish queen renews China ties. China Daily 25 April. URL: http://www.chinadaily.com.cn/world/2014-04/25/ content_17463506.htm (accessed 1 September 2016).

Linklater, A. and H. Suganami. 2006. The English school and international relations. Cambridge: Cambridge University Press.

Liu, N. 2016. Can the Polar Code save the Arctic?' American Society of International Law 20(7) URL: https://www.asil.org/ insights/volume/20/issue/7/can-polar-code-save-arctic (accessed 15 April 2016).

Liu, J., Z. Chen, J. Francis and others. 2016. Has Arctic sea ice loss contributed to increased surface melting of the 
Greenland Ice Sheet? Journal of Climate 29(9): 33733386.

MacDonald-Gibson, C. 2013. From China to Rotterdam, and into the record books. The Independent 12 September.

Marson, J. 2013. Russian natural-gas project gets funding from China. Wall Street Journal 29 April 2016.

McKeown, R. 2009. Norm regress: US revisionism and the slow death of the torture norm. International Relations 23(1): 525.

NSIDC (National Snow and Ice Data Center). 2015. Arctic sea ice reaches fourth lowest minimum. 15 September, URL: http://nsidc.org/arcticseaicenews/2015/09/2015_ arctic-minimum (accessed 1 April 2016).

NSIDC (National Snow and Ice Data Center). 2016. The Arctic sets yet another record low maximum extent. 28 March. URL: http://nsidc.org/news/newsroom/ arctic-sets-yet-another-record-low-maximum-extent. (accessed 1 April 2016).

News.com.au. Shenghe takes 12.5 stake in GGG. 23 September 2016. URL: http://www.news.com.au/finance/ business/breaking-news/shenghe-takes-125-stake-in-ggg/ news-story/9b87c3778c4ebf3deb4156f22a1fb367. (accessed 18 October 2016).

Ning, X. 2009. 地球未来的缩影 一 外交部长助理谈北极研究 之旅 [A microcosm of the world's future-Assistant Minister of Foreign Affairs talks about High North study tour]. Shijie Bolan [World Vision] 349(19): 58, 59.

Paris, C. and J. Chu. 2015. Chinese shipping group Cosco planning regular trans-Arctic sailings. Wall Street Journal 29 October 2015. URL: http://www.wsj.com/ articles/chinese-shipper-cosco-to-schedule-regular-transarctic-sailings-1446133485 (accessed 12 December 2015).

Payne, R.A. 2001. Persuasion, frames and norm construction European Journal of International Relations 7(1): 37-61.

Peng, Y. 2016. China charting a new course. China Daily 20 April 2016. <http://www.chinadaily.com.cn/china/2016-04/ 20/content_24679000.htm (accessed 21 April 2016).

People's Daily. 2013. 积极参与北极合作 (Active participation of Arctic cooperation). 22 March 2013. URL: http://world.people. com.cn/n/2013/0322/c1002-20874313.html (accessed 12 June 2015).

Raspotnik, A. 2016. 'Solar-Terrestrial' interaction between Iceland and China. High North News 4 April 2016. URL: http://www.highnorthnews.com/ solar-terrestrial-interaction-between-iceland-and-china (accessed 5 April 2016). CH

Robinson, R.W. Jr. 2013. China's 'long con' in the Arctic. MacDonald-Laurier Institute Commentary (September 2013), URL: http://www.macdonaldlaurier.ca/files/ pdf/MLIChina'sLongConInTheArctic09-13Draft4-1.pdf (accessed 17 March 2016).

Røseth, T. 2014. Russia's China policy in the Arctic. Strategic Analysis 38(6): 841-859.

Rothwell, D.R. 1993. The Canadian-US northwest passage dispute: a reassessment. Cornell International Law Journal 26(2): 331-372.

Rt.com. 2016. Russia submits revised claims for extending Arctic Shelf to UN. 10 February, URL: https:/www.rt.com/ news/332089-russia-arctic-claim-un (accessed 11 February 2016)

Russia, Northern Sea Route Information Office. 2016.: http:// www.arctic-lio.com/nsr_transits (accessed 5 March 2016).

Saroka, G. 2016. Putin's Arctic ambitions: Russia's economic aspirations in the far north. Foreign Affairs 5 May 2016. URL: $\quad$ https://www.foreignaffairs.com/articles/russia-fsu/ 2016-05-05/putins-arctic-ambitions (accessed 6 May 2016).
Shambaugh, D. 2013. China goes global: the partial power. Oxford and New York: Oxford University Press: 269306.

Sigurðardóttir, L.H. 2016. Ekki vísun að fastri viðveru [Do not assume a permanent presence]. Mblis, 30 June, URL: http://www.mbl.is/frettir/innlent/2016/06/30/ekki_visun_ ad_fastri_vidveru/ (accessed 12 September 2016).

SIPRI (Stockholm International Peace Research Institute). 2012. China defines itself as a 'near-Arctic state'. Stockholm International Peace Research Institute (SIPRI) 10 May 2012. URL: http://www.sipri.org/media/pressreleases/2012/ arcticchinapr (accessed 12 March 2016).

Smith, L.C. and S.R. Stephenson. 2013. New trans-Arctic shipping routes navigable by midcentury. Proceedings of the National Academy of Sciences of the United States of America 110(13). URL: http://www.pnas.org/content/110/13/ E1191.full (accessed 5 December 2015).

Solli, P.R., E. Wilson Rowe and W. Yennie Lindgren. 2013. Coming into the cold: Asia's Arctic interests, Polar Geography 36(4): 253-270. $\mathrm{CH}$

Stensdal, I. 2014. Chinese climate-change policy, 1988-2013: moving on up. Asian Perspective 38(1): 111-135.

Stewart, P. 2015. Five Chinese ships in Bering Sea as Obama visits Alaska. Reuters 2 September. 2015 URL: http://www.reuters.com/article/ us-usa-china-military-idUSKCNOR22DN20150902 (accessed 5 September 2015).

Strader, O. 2012. Arctic Council security agreement: preventing militarization and ensuring stability and security - part II. 18 January 2012. The Arctic Institute: Centre for Circumpolar Studies. URL: http://www.thearcticinstitute.org/2012/ 01/12234-arctic-council-security-agreement.html (accessed 5 February 2016).

Struzik, E. 2013. China signals hunger for Arctic's mineral riches. The Guardian 4 June. 2013.

Sweden, Ministry of Foreign Affairs. 2012. Statement by H.E. Ambassador Lan Lijun at the meeting between the Swedish chairmanship of the Arctic Council and observers, 6 November 2012. URL: http://www.arctic-council. org/images/PDF_attachments/Observer_DMM_2012/ ACOBSDMMSE01_Stockholm_2012_Observer_Meeting_ Statement_Ambassador_Lan_Lijun_China.pdf (accessed 2 May 2016).

Tan, T. 2011. Freeze! You're in Mohe. China Daily 6 January 2012. URL: http://www.chinadaily.com.cn/cndy/2011-01/06/ content_11800824.htm (accessed 5 April 2016).

Tang, G. 2013. Arctic issues and China's stance. China International Studies 38: 29-48.

Tîrnoveanu, D. 2016. Russia, China and the far east question: are there any Chinese $49^{\text {ers }}$ around? The Diplomat 20 January 2016. URL: http://thediplomat.com/2016/01/ russia-china-and-the-far-east-question/ (accessed 2 February 2016).

United Nations, United Nations Office on Human Rights. 2007. Declaration on the rights of indigenous peoples. September 2007.: United Nations Office on Human Rights. URL: http://www.ohchr.org/EN/lssues/IPeoples/Pages/Declaration. aspx (accessed 12 May 2016).

Vanderklippe, N. 2014. For China, north is a new way to go west. Globe and Mail 19 January. 2014

Vanderklippe, N. 2015. Chinese scientists look to Canadian Arctic for research outpost. Globe and Mail 18 March 2015, URL: http://www.theglobeandmail.com/ report-on-business/industry-news/energy-and-resources/ chinese-scientists-dream-of-arctic-research-outpost-in-thenorth/article23527009/ (accessed 29 August 2016). 
Vickers, B. 2013. Africa and the rising powers: bargaining for the 'marginalized many'. International Affairs 89(3): 673-693.

Wang, X. 2013. 国家利益视角下的中国北极身份 [China's Arctic identity from the perspective of national interests], 太平洋学 报 Pacific Journal 5: 81-89.

Wilson, P. 2016. Society, steward or security actor? Three visions of the Arctic Council. Cooperation and Conflict 51(1): 55-74.

Winger, G. and G. Petursson. 2016. Return to Keflavik Station: Iceland's cold war legacy reappraised. Foreign Affairs 24 February 2016. URL: https://www.foreignaffairs.com/ articles/united-states/2016-02-24/return-keflavik-station (accessed 1 March 2016).

Xinhua. 2013.专访: 中国愿为北极地区可持续发展作出贡献 [Interview: China willing to contribute to sustainable development in the Arctic]. Xinhua 23 March 2013. URL: http://www.gov. cn/jrzg/2013-03/23/content_2360686.htm (accessed 7 June 2015).

Xinhua. 2004. Yellow River Station opens in Arctic. China Daily 29 July 2004.

Xinhua. 2015. China's energy giant willing to cooperate in Arctic resources extraction. China Daily / Xinhua 20 January, URL: http://europe.chinadaily.com.cn/business/2015-01/ 20/content 19354337.htm (accessed 25 January 2015).

Xinhua. 2016. Chinese scientists complete $32^{\text {nd }}$ Arctic expedition. Xinhua 13 April 2016.

Xu, X. 2016. China to further explore Antarctic, deep sea this year. Xinhua 9 February 2016.
Yang, Z., Cui, J., Han, S. and two others. 2013. 北极生态安 全对中国国家安全的影响及应对策略 [Arctic ecological safety and China's national security and coping strategies]. 海洋环境科学 Marine Environmental Science 4: 629635.

Ye, J. 2014. China's role in Arctic affairs in the context of global governance. Strategic Analysis 38(6): 913916.

Yu, J., Z. Xie, H Kang and others. 2014. High variability of atmospheric mercury in the summertime boundary layer through the central Arctic Ocean. Nature 15 August, URL: http:// www.nature.com/articles/srep06091. (accessed 3 September 2016).

Zhang, M. 2015. Keynote speech by Vice Foreign Minister Zhang Ming at the China country session of the third Arctic Circle assembly. 17 October 2015. Foreign Ministry of the People's Republic of China. URL: http://www.fmprc.gov.cn/mfa_eng/ wjbxw/t1306858.shtml (accessed 5 December 2015).

Zhang, X, Yang, H. and Luo, W. 2016. 我国北极航道开拓的战 略选择初探, [Strategic thinking on China's involvement in the development of Arctic Sea routes], Chinese Journal of Polar Research 28(2): 267-276.

Zvezda. 2015. Шойгу: военное присутствие в Арктике - вопрос национальной безопасности [Shoigu: military presence in the Arctic - A matter of national security], Zvezda 25 February 2015. URL: http://tvzvezda.ru/news/vstrane_i_mire/content/ 201502251655-6b5l.htm (accessed 3 May 2016). 